\title{
A state in search of Archipelago
}

\begin{abstract}
In the Comoros, the state building faces the geographical features of the country (insularity and archipelity), originally different social identities. Several solutions have been adopted to transcend identity and territorial peculiarities, like the constitutional amendment. Since 1975, when the archipelago gained independence, the constitution was revised nearly five times without can't absorb the political crises separatist or irredentist.
\end{abstract}

Keywords: insularity, ileitis, archipelity, remoteness, Africa, Comoros Islands, State, nation, identity
Volume 4 Issue 2 - 2019

\author{
Adjimaël Halidi \\ Sociologist and Expert Analysis and Evaluation of Public Policies, \\ East Africa \\ Correspondence: Adjimaël Halidi, Sociologist and Expert \\ Analysis and Evaluation of Public Policies, Comoros, East Africa, \\ Email adjmael.halidi2@gmail.com
}

\section{Introduction}

Located in Indian Ocean, between Madagascar and Mozambique the Comoros Islands ${ }^{1}$ (Figure 1) extend over an area of 2034 square kilometers. The state control of the archipelago has always faced constraints on geographical, historical and sociological. That's the way, the archipelity highlights a governmentality whose shape differs from state systems known in the West, which are characterized by centralization of neutral political and administrative bodies and equitable coordination of these on the whole territory, ${ }^{1}$ originally a collective consciousness and a social link. ${ }^{2}$ In practice, the Comorian State struggling to deploy across its territory, he can't do balance the geographic disparities and identity aspirations of the people of each island. In these circumstances, the islands of Mayotte, Moheli and Anjouan, feeling relegated to the position of remoteness. ${ }^{2}$

This opposition between center/periphery is manifested through political claims referred to separatist or irredentist. Irredentism first since the island of Mayotte chose to remain French in 1975, while the other sister islands opt for independence. This choice to remain within the French Republic, supported by the Mahore People's Movement (MPM) since 1958, following the decision of the Territorial Assembly of the Comoros to transfer the capital, initially based in Dzaoudzi (Mayotte) to Moroni on Great Comoro, ${ }^{3,4}$ led to the accession of Mayotte to the status of department french overseas region in $2011 . .^{5}$ Separatism then, in 1991 on the island of Moheli, residents have replaced the flag of the Comoros with a yellow and red flag, symbol of the break and independence. The moheliens separatist demands the integration of the autonomy of the islands and equality between the islands in the Constitution. A National Reconciliation Pact was signed on 27 December 1991 between separatists and the central island. ${ }^{6}$ Six years later, in July-August 1997, another separatist fever seizes Moheli, but too Anjouan. In the center of discord, is the denunciation of a discontinuity of the state or a situation of isolation of these islands, in other words a excessively-insularity. ${ }^{7}$ The separatist crisis was shortlived in Moheli, but in Anjouan she is lasted until February 2008, date the national Comorian Army (NDA), aided by the Pan-African troops, went flush out protesters from central government. These political expressions of rejection of the other called the insularism. ${ }^{8,9}$

${ }^{1}$ The archipelago consists of four islands: Great Comoro, Anjouan, Moheli and Mayotte. Mayotte remained French after of independence of the first three in 1975. The Comoros population is estimated between 700000 and 800000 .

${ }^{2}$ The costs of air and sea transport are prohibitive for the majority of the Comorian population. These excessive costs are not in fact proportional to the distance that of islands between them. This reinforces the isolation of the islands since the circulation of goods and people is difficult in the archipelago.
Thus, to prevent or minimize the effects of insularism, the Comoran State has adopted since 1978 various Constitutions. The 1978, which recognized the insularity of each island, had opted for a federation of autonomous islands. This institutional recognition of the autonomy of the islands and equality between the islands was a requirement of BPM to integrate the new republic. The Constitution, however, was revised in 1982; the island dimension has been removed, following the refusal of Mayotte to integrate the new Comorian republic. In December 2001, the Comorian State adopts a new Constitution and abandon the name Islamic Republic of the Comoros (IRC) in favour of the Union of Comoros. The new Constitution recognizes every island relative autonomy and establishes a rotating presidency between islands.? The prime minister has been removed, so that now each autonomous island is represented to the President of the Union by a vice president. Subsequent to the constitutional reform of 17 May 2009, the insular executive (formerly known presidents of the autonomous islands) took the title of governor following the constitutional revision of 30 July 2018, the prime minister returns over those of vice-presidents.

The above begs the question: how the modus vivendi of the Comorian people they influence the modus operandi of the state and vice versa? To answer this question, we mobilize a number of concepts such as territoriality (I) and identity (II). Mobilizing these concepts, we will analyse the episteme of State in a context of multiinsulary and underdevelopment.

\section{Continuity and territorial discontinuity}

If a society is defined first by its imaginary, ${ }^{11}$ the territory gives this imaginary a materiality. Thus, in the manner of time-space Giddens, ${ }^{12}$ the spatial practices of individuals harbor a dynamic both real and cognitive, reifies by the relationship to the symbolic (social interaction, stories, landscapes, places...). Etymologically, symbol derives from the Greek word "symbolein" to put together "put together"; its opposite is "diabolein" which means "to separate". However, the symbol has as both an integrator and dividing role. If any symbol includes individuals in the same frame of reference, it also excludes everything that is out of this frame of reference. In this perspective, territoriality, which refers to the mental appropriation of the territory by the individual, promotes the development of a sense of spatial belonging. This sentiment is perceptible through cultural expressions, artistic and social populations. Regarding the insular spatiality the feeling of owning an original identity or a culture specific to a specific insular called ileitis. ${ }^{13}$ Under these conditions, the archipelity Comoros encourages the development of clean ileitis each island. Each the Comoros Islands remain as distinct by physical and human 
personality. These heterogeneous individualities, not comparable, deeply marked the ethos of each island group. This difference in ethos is expressed among others in how to represent Comorians government. It does not carry the same symbolic weight in each island. In Anjouan and Mayotte, the reference system of governance is the sirkali which is symbolically and physically omnipresent political organization in the country. ${ }^{3}$

\section{The sirkali}

First populated by Bantu and Austronesian mongrel called Waaq Waaq ${ }^{14}$ or proto-Malagasy, as considered ancestors of Antalotes, Malagasy tribe of Mahajanga region, ${ }^{15}$ the archipelago of the Comoros was successively colonized by Arab-chiraziens (before the eleventh century) then by the French in $1841 .{ }^{16}$ In the manner of Arab-Muslim conquests known elsewhere, ${ }^{17}$ since the boundary between slavism expansion and colonialism expansion was small, Arab-chiraziens were massively established in Anjouan and Mayotte to practice slavery and trafficking men. These islands had attracted the interest of slaving and Arab-chiraziens planters, then European, firstly for their coastal areas suitable for port activities, as generous in deep water. Western mercantilist thought had also submitted the Environment for colonization..$^{18}$ From Africa to the Americas, to Asia, the colonial powers regarded nature as a commodity. Excessive cuts were made in the forests and trees have been replaced by export crops: cotton, sugar cane, etc. The ecosystem was replaced by the agrosystem. ${ }^{19}$ In the Comoros, the French colonial administration had recovered all the land of Mayotte ${ }^{20}$ and nearly two thirds of those of Anjouan: ${ }^{15}$ the land had served planting of export crops like vanilla, cloves, coconut (copra).

The symbolic violence regimes of the Arab-chiraziens and French planting then made the Anjouan and Mayotte poepole sensitive to the sirkali symbols. The sirkali is a politically and symbolically organized, exercising sovereign power very strong, which is manifested by the monopoly of legitimate violence and the fiscal monopoly. This definition borrowed from Weber ${ }^{21}$ and Elias ${ }^{22}$ allows us to define the sirkali of modern state Western. Furthermore, if the modern state is a politically organized society, guarantee the order and security of citizens, ${ }^{23}$ Securing, controlling and disciplining individuals, threebreaking dimensions of the modern state were never applied equally to all people of Anjouan and Mayotte. Ultimately, the sirkali was never a political system oriented towards the common good, but rather an unequal system of domination and adjustment to the benefit of the colonizers. The dominated already reduced to conditions of bonded labor or korove (translation to word French "corvée") in plantations, were also forced to pay the tax (latete in Comorian language).

In summary, a dichotomy or a segregated application of power has always prevailed in the colonial regimes chiraziens Arab and French. The colonial regime Arabian chiraziens based on differentiation and identification compared to the phenotype or the place of origin of individuals, the French colonial rule between, within the islands, the various socio-historical categories. For example, in Anjouan, the French government speared the class of colonialists, the class families "aristocrats" of Arab origins chiraziennes "maKabaila and wan Gwana" and indigenous "waMatsaha". ${ }^{15}$ The first two classes were side by side the ruling classes and the third, marginal or subordinate class. Thus, the relations of domination of the Arab-chiraziens first settlers, French

${ }^{3}$ For a better understanding of the concept of "Yezi" read especially Ben Ali D 2008. "The dichotomy between traditional and modern institutions institutions" In Ya Mkombe No. 16-17. then made the Comorian population juxtaposition of communities linked together by relations of power and unequal interactions. These servo relations maintained between masters and slaves or between the colonial powers and the colonies, by symbolic violence and exchange hardware and services, made what some experts call the "colonial relationship". As demonstrated by researchers specializing in sociology of colonization, including Albert Memmi ${ }^{24}$ and Frantz Fanon, ${ }^{25}$ the interactions between dominant and subordinate create constant subordination effects otherwise unequal social relations that neither abolition of slavery or decolonization could never liquidate. ${ }^{4}$ The finished colonization, a colonial relationship always prevails in Mayotte and manifested by the current subordination psychic of Mayotte to France. Among other assumptions, because the colonial conditioning, all ready to believe that the absence of strong symbols in the Comorian state, the Anjouan population, like Odysseus and his companions bewitched by the clear song of the Sirens, struggling through movements separatist or irredentist to compensate for their psychological thirst for missing state symbols.

\section{The Yezi}

Moheli being cramped $\left(290 \mathrm{~km}^{2}\right)$, had remained for a long time without wearing. As for Great Comoro, it is devoid of rivers and streams, but remains however with many ravines unfortunately often dry, ${ }^{26}$ and the water absorbed by the porous soil dissipates quickly. In these islands, colonial plantations, like those of Mayotte and Anjouan, appeared later: respectively in 1865 with the arrival of Joseph Lambert and in Moheli in 1885, with the coming of Léon Humblot to Great Comoro. Great Comoro island at the southern tip of the archipelago, the Arab-chiraziens there also arrived late [perhaps from Anjouan], and in small numbers. Thus, contrary to Anjouan and Mayotte where regimes planting and colonization have a symbolic and physical coercion caused ethnocide, ${ }^{15}$ Great Comoro people have had a lot more leeway to preserve their original identity. Slavery in Great Comoro was rather domestic, that is to say a court of slavery. The slave populations were largely composed of people born free, but fallen into slavery for committing a misdemeanor or a felony. It also had people sold by their families in times of famine. These people lived together in neighborhoods or villages extramural called itreya. ${ }^{27}$ This domestic slavery allowed the Great Comoro retain their ancestral social organization, ${ }^{28}$ even though it was basically impregnated or solidified by Islam. Otherwise, this continuum of ancient traditions in Great Comoro was extended even during the French colonization, ${ }^{28}$ thanks to the Yezi, he is power proximity based on small territorial entities, namely the villages. Also, note that the village serves jurisdiction, especially in personal or land disputes; which has an impact in substitution to the state, otherwise its loss of legitimacy. The traditional leaders are, compared to the political elite, alternative authorities, since locally replace state actors to such an extent that they constitute an obstacle to the postcolonial state, since it removes any reason. They disempowering. In summary, the Great Comoro have fragmented representation of their social space. Notable villagers and has more legitimacy, authority and influence the state

${ }^{4}$ Edward Said ${ }^{29}$ likens the "colonial relationship" to a "colonial imagination." He defines it as the result of the entanglement of the world of the colon with the world of the colonized through a dominant culture as the best means to establish hegemony forever. For its part, Rajeev Bhargava ${ }^{30}$ calls this cultural inferiority (intellectual and cognitive) of dominated by the dominant epistemic injustice. In Africa, as Ngugi wa Thiongo, ${ }^{31}$ Joseph Tonda $^{32}$ argues that the Western imagination, conveying pernicious utopias through modern communication tools, annihilates the imagination of Africans. He describes this annihilation by Western utopias of"afrodystopie". 
and its representatives. It thus appears that the Yezi carries a power of sanctification and desecration. It honors the individual as can the pillory. The Yezi is at the origin of ethnocentrism. Levi Strauss ${ }^{33}$ defines it as the blissful naivety to believe that "humanity stops at the borders of the tribe, language group, sometimes the village." Thus, we understand the lack of interest that the Great Comoro gives state symbols and why they often replace him.

\section{Two different approaches to governmentality}

These two approaches to governmentality namely sirkali and Yezi, which can be defined in two ileitis crossed history. The French colonization never sought to change the sociopolitical organization of its colonies. If the name of "the indivisibility of the Republic, equality before the law and of the unity of the French people", "Jacobin ideology (...) has always denied the ethnic diversity of the French population", ${ }^{34}$ France has always separated the Republic Colonies, practicing segregation between metropolis and those. The very idea of a nation, indivisible never concerned the colonies where the particularities of the natives and their territories were maintained or even strengthened. They were French nationals, without being citizens, and thereby have the title subject. This legal pluralism of the French Republic, stated in the Constitution of 1958 will be characterized by the maintenance of local features of these territories. In addition, France has never had plans to deploy its political organization on its colonies. She had just set up an economic-administrative apparatus facing exploitation and export of raw materials. In practice, the French colonial administration has always reinforced ileitis of each island. The current partition of the archipelago by partial decolonization (an independent Comoros side, the other Mayotte under French control) reflects the aims of old colonialists. ${ }^{5}$ Ultimately, the colonial legacy and become orthodoxy remains a challenge for the young Comorian State, which is struggling to reconcile its various ileitis. ${ }^{35}$ The socioeconomic development, relatively variable between the islands and between populations, facing the Comoros and Mayotte today, so rooted in the colonial past.

\section{National identity}

Identity is a social construct. ${ }^{36,37}$ Under these conditions, it can be deconstructed, finicky at best so that it is suitable and adaptable to spaces, places and territories. That said, territoriality contains an identity dimension. ${ }^{38}$ Thus, beyond the tangible or imaginary social cleavages, different territoriality can be unified, consolidated, in order to produce a collective identity. And the state is better equipped to achieve this social process, since through-identifiable institutions (Civil status for example) or socializing institutions (school for example) can produce a legitimate collective identity. The State is therefore conducive to a balanced relationship of symbolic power between different territorialities equitably distributing power and economic and infrastructural capital in geographic space. This production of a common social destiny unconditionally based on democracy within the meaning of Homi K Bhabha, ${ }^{39}$ is one to say "democracy derealized" which translates as a creative power of people national unity. In practice, Ileitis being about identity resolutely not a serious obstacle to the creation of national unity, and consequently is not an obstacle to

${ }^{5}$ Since December 22, 1974, Mayotte became a bone of contention between France and the Comoros. This Franco-Comorian dispute was the subject of the resolution 3385 of 12 November 1975 the United Nations General Assembly stating "the need (of France) to respect the unity and territorial integrity of the archipelago Comoros consists of the islands of Anjouan, Great Comoro, Mayotte and Moheli. " socio-economic development of the Union of Comoros. In addition, exacerbation of ileitis can cause adverse events. This exacerbation may be promoted by a chaotic political or social situation or precursors, mainly political and intellectuals in bad visibility or regeneration, and which their first concern is to mobilize ethnic sentiments or regionalist in order to conquer or to retain power. The negative character of ileitis is known under the term of "insularism".

In the Comoros, the insularism is a set of events from a social imaginary whose images, original or inherited, among other archetypes of the different colonial regimes, expressed by civilians or armed conflicts, latent or open between the different islands (see above).

Finally, insularism prevents both building a state and a nation Comoros. The State takes the form of well-defined symbols like the flag, the constitution, national anthem, the Administration, among others, and was incarnate by political leaders and officials. ${ }^{23}$ However, the nation rather refers to a real fictional, abstract, to a building. Renan $^{40}$ develops the Nation as "the desire, the will and consent" to live together, Benedict Anderson ${ }^{41}$ defines it "as an imaginary political community, and imagined as inherently limited and sovereign." In other words, making nation, it is the spirit of belonging to one body: a national imaginary. So it is not culture, nor religion, let alone race. Noting that "even in societies that call themselves the most" civil ", ethnic peculiarities and idiosyncrasies are maintained and even renewed" Shnapper ${ }^{42}$ that defines the nation as a "community of citizens", says to do Nation, "transcendence of ethnic realities of concrete society [historical origins (in the broad sense) or ethnicreligious] by the civic principle [individuals civilly, legally, politically free and equal]" is required. In terms of the archipelagic Comorian entity, it now seems emptied of all this national imagination needed to transcend identity particularities. In short, citizenship as membership and participation in the community does exist in the Comoros, Nevertheless, this citizenship is limited to the village or the island. Hence the need to focus on building "third space", if one may use the term Bhabha. ${ }^{43}$

The logic is that building a nation is made on the basis of the lessons of objective history (there are also the myths-of a subjective naturewhich are a symbolic representation of a remarkable experience, carrying an ideal, allowing to create in the national imagination this common feeling of belonging to a community), a common national language and civic education (reference figures, national monuments and heritage). The example of the Enlightenment is quite suggestive; it shows how the French nation was built by the French State and the violence [physical and symbolic]. In this sense, for there to nation, it is imperative people: men who agree to link their destiny despite their socio-ethnic differences, as in India, socially fragmented country by his caste, but united politically by spirit of nation that is shared by all citizens. However, like any superstructure rests on an infrastructure, a reconciliation of the regions, often dissimilar to one another by sideboards road, water and air quality, is crucial in building a nation, as is the case in the United States where transport sector development has contributed to national unity. Thus, the nation is a "creative utopia" or "fiction" which portrays the "legal subjects" who, by a common political imagination, transcend their particularities to advance hand in hand. ${ }^{42}$ Finally, it is through the rule of law, a national school and a better-wide transport system archipelagic to reduce remoteness and excessively-insularity different islands Comoros could build a nation an indivisible and attached to the same values. 


\section{Conclusion}

As the conatus Spinoza, the state tends to increase in order to control the whole territory. By cons, Comoros, the state, as an apparatus bureaucratic, regresses to the point of being non-existent in much of the territory. Thus, the state neither does Comorian shapes nor transcends society; it is rather dominated and shaped by it. Ileitis is such that the country remains torn between Yezi and sirkali, and these territorial and community logics that give individuals their identity. An identity that never exceeds village or the island: infranational identity. The citizens, instead of identifying with the State, always the traditional loyalties and allegiances continue to represent their country in a fragmented way, atomized. In this perspective, if the Comoran State has been recognized by other states constituting the international community, it is nevertheless a cryptarchie ${ }^{6}$ In the sense that it can not fulfill its primary function, i.e. take care of the welfare of all its citizens. Symbolic State absence in much of the Comorian territory prompts us to consider the Comorian State as erosive, since failure to ensure the welfare of its people; it pushes them to conditions of social existence deadly of which the most obvious is the illegal crossing to Mayotte, with a wealth of drowning. This denial of citizenship to most of the Comorian population, a result of massive dead, is that Achille Mbembe ${ }^{44}$ calls "the necropolitical". The latter is also justified by the repetition of the civil and armed conflict, mowing many lives. ${ }^{7}$ Finally, it is time for a real symbolic revolution oriented towards statehood and identity across geographic particularities. To do this, the adoption of a system of government based on voluntarism or more rational decisions such as Herbert $\operatorname{Simon}^{46}$ recommends in its work, it is most urgent. That is to say transforming action systems based on the actors themselves and their identity features in order to reach consensus, that is to say a doxic adherence to national identity. This is thanks to this reflexive modernization ${ }^{47}$ that will emerge State and Nation worthy of the name..$^{48-54}$

\section{Acknowledgments}

None.

\section{Conflicts of interest}

Author declares that there is no conflict of interest.

\section{References}

1. Badie B, P Birnbaum. State sociology. Paris: Fayard/Plural; 1983.

2. Bourdieu P. On the state. Courses at the College de France (1989-1992). Paris: Seuil; 2012.

3. Ahmed C. Islam and politics in the Comoros. Paris: L'Harmattan; 1999.

4. Blanchy S. Mayotte and their land. Local origins, identity and politics. Rights and Cultures; 1999; 37 p.

5. Idriss M. Mayotte department, The end of a fight? The Mahoré People's Movement: between opposition and Francophile (1958-1976). Contemporary Africa. 2013;3(247):119-135.

6. Perri P. Comoros: new mercenaries. Paris: L’Harmattan; 1994.

7. Taglioni F. Separatist and autonomist claims within states and monoand multi-island territories: typology. Geography of Cahiers du Québec. 2005;49(136):5-18.

${ }^{6}$ Neologism created by Bruno Fuligni ${ }^{45}$ to designate virtual entities with state appearance without being concretely.

${ }^{7}$ As of October 15, 2018 a violent insurrection, which lasted a week, killing at least three dead in Anjouan. This umpteenth armed conflict in the country, coupled frequent inter-village conflicts Great Comoro, reveals political instability, so a state fragility.
8. Mercier G. Insularity Study. Islands and island societies. Norse Review. 1990;145:9-14.

9. Bernardie-Tahir N. The other Zanzibar. Geography of against-insular. Paris: Karthala; 2008.

10. Taglioni F. Small island areas facing the variability of their insularity and their political status. Annals of Geography. 2006;652:664-687.

11. Castoriadis C. The imaginary institution of society. Paris: Seuil; 1975.

12. Giddens A. The constitution of society: Outline of the theory of structuration. Berkeley, CA: University of California Press; 1984.

13. Moles AA. Nissonologie science of islands. Geographic Space. 1982;11(4):281-289.

14. Verin P. Comoros. Paris: Karthala; 1994.

15. Robineau C. Society and economy of Anjouan. Paris: ORSTOM; 1966.

16. Martin J. Comoros islands between four pirates and planters. Paris: L'Harmattan; 1983.

17. Lewis B. Race and color in Islam. New York-London: Harper and Row; 1971.

18. Regourd F. Mastering nature: a colonial issue. Botany and agronomy in Guyana and the Caribbean (XVII-XVIII centuries). French Review story overseas. 1999;86:322-323.

19. Mbembe A. Necropolitics. Public Culture. 2003;15(1) :11-40.

20. Blanchy S. Mayotte French Life. French Ethnology. 2002;32:677-687.

21. Weber M. The learned and the policy. Paris: Plon; 1963.

22. Elias N. The Dynamics of the West. Paris: Calmann-Levy; 1976.

23. Braud P. Think the state. Paris: Seuil; 1997.

24. Memmi A. Portrait of the colonized colonizer preceded Portrait. Paris: Gallimard, Folio Actuel; 2002.

25. Fanon F. The Wretched of the Earth. Paris: Maspero; 1961.

26. Guebourg JL. La Grande Comore. Sultans mercenaries. Paris: L'Harmattan; 1993.

27. Ben Ali D. Mixed cultural and cultural specificity Comoros. Online Indian Ocean countries. 2001-2002;17.

28. Chouzour S. The honor power. Paris: L'Harmattan; 1994.

29. Said E. Culture and imperialism. Knopf : New York; 1994.

30. Bhargava R. Overcoming the Epistemic Injustice of Colonialism. Global Policy. 2013;4(4):413-417.

31. Wa Thiong'o N. Decolonising the Mind. Portsmouth: Heinemann; 1986.

32. Tonda J. Imperialism postcolonial. company's critical glare. Paris: Karthala; 2015.

33. Levi-Strauss C. Race and History. Paris: Denoël; 1987.

34. Barth F. Ethnic groups and their borders. In: Poutignat P, Streiff-Fenart J, editors. Preface of Lapierre, Theories of ethnicity, coll. Sociologist. 1995.

35. Walker I. What Came First, the Nation or the State? Political Process in the Comoros Island. The Journal of the International African Institute. 2007;77( 4) :582-605.

36. Berger P, Thomas Luckmann T. The Social Construction of Reality: A Treatise its the Sociology of Knowledge. New York: Anchor Books; 1966.

37. Goffman E Stigma. Notes on the Management of Spoiled Identity. Prentice-Hall: Englewood Cliffs; 1963.

38. Di Meo G. Identity: An Essential Report mediation space/society. Géocarrefour. 2002;77(2):175-184 
39. Bhabha H. Learning about democracy. Or democracy de-realized. Diogenes; 2002. 197 p.

40. Renan E. What is a nation? 1882.

41. Anderson B. Imagined Communities, Reflection on the Origin and Spread of Nationalism. London: Verso; 1983.

42. Schnapper D. The community of citizens. Paris: Gallimard; 2003.

43. Bhabha H. The Location of Culture. New York: Routledge; 1994.

44. Mbembe A. Enmity Policies. Paris: Discovery; 2016.

45. Fuligni B. The state is me. History of private monarchies, principalities of fantasy and other pirate republics. Paris: Editions of Paris, 1997.

46. Simon H. The Sciences of the Artificial. Cambridge: MIT Press, Massachusetts; 1969.
47. Beck U. Risk Society: Towards a New Modernity. New Delhi: Sage; 1992.

48. Bernardie-Tahir N. The use of the island. Paris: Petra; 2011.

49. Bonnemaison J. Living on the island: An approach to Pacific ileitis. Geographical space. 1990;19-20(2):119-125.

50. Crozier, Friedberg E. The actor and the system. Paris: Seuil; 1977.

51. Foucault M. Security, Territory, Population. Paris: Seuil; 2004.

52. Gramsci A. Prison Notebooks. Paris: Gallimard; Philosophy Library, 5 volumes; 1978-1992.

53. Ibrahime M. French State and settlers in the Comoros (1912-1946). Paris: L'Harmattan; 1997.

54. Mahamoudou S. Land and society in the Comoros. The time of refoundings. Paris: Karthala; 2009. 